\title{
Diagnosis and treatment of primary central nervous system lymphoma with the primary lesion in the hypothalamus: a case report
}

Ken Takao ${ }^{1 \dagger}$, Ayaka Tani ${ }^{1 \dagger}$, Tetsuya Suwa ${ }^{1 *}$, Yayoi Kuwabara-Ohmura', Kenta Nonomura ${ }^{1}$, Yanyan Liu', Takehiro Kato', Masami Mizuno', Takuo Hirota', Mayumi Enya', Katsumi lizuka', Yukio Horikawa', Chiemi Saigo², Yusuke Kito ${ }^{2}$, Tatsuhiko Miyazaki ${ }^{2}$, Naoyuki Ohe ${ }^{3}$, Toru Iwama ${ }^{3}$ and Daisuke Yabe ${ }^{1 *}$ (D)

\begin{abstract}
Background: Primary central nervous system lymphoma is a rare extra-nodal lymphoma of the central nervous system. Primary central nervous system lymphoma lesions usually appear in the vicinity of the ventricle, and there are few reports of primary central nervous system lymphoma with hypothalamic-pituitary lesions.

Case presentation: We treated a 56-year-old male with primary central nervous system lymphoma with the primary lesion in the hypothalamus, which was found by magnetic resonance imaging after sudden onset of endocrinological abnormalities. Initially, he was hospitalized to our department for hyponatremia. Endocrinological examination in conjunction with head magnetic resonance imaging and endoscopic biopsy revealed hypothalamic hypopituitarism and tertiary hypoadrenocorticism caused by a rapidly growing, diffuse large B-cell lymphoma in the hypothalamus. Remission of the tumor was achieved by high-dose methotrexate with whole brain radiotherapy, and some of the hormone responses were normalized.
\end{abstract}

Conclusions: While primary central nervous system lymphoma is rare, it is important to note that hypopituitarism can result and that the endocrinological abnormalities can be partially restored by its remission.

Keywords: PCNSL, Hypothalamus, Hypopituitarism, Case report

\section{Background}

Primary central nervous system lymphoma (PCNSL) is an extra-nodal lymphoma that shows no lesions other than in the central nervous system at the time of diagnosis [1]. While the disease is relatively rare, comprising $1-$ $5 \%$ of brain tumors, the number of PCNSL cases is increasing recently $[2,3]$. PCNSL is frequently found in

\footnotetext{
*Correspondence: suwa@gifu-u.ac.jp; ydaisuke-kyoto@umin.ac.jp

${ }^{+}$Ken Takao and Ayaka Tani contributed equally to this work.

'Department of Diabetes and Endocrinology, Gifu University Graduate School of Medicine, 1-1 Yanagido, Gifu 501-1194, Japan

Full list of author information is available at the end of the article
}

association with acquired immunodeficiency syndrome (AIDS) in western countries; most PCNSL cases in Japan are without AIDS and tend to be found in individuals age 50-70 in whom the disease progresses from B lymphocytes [4]. PCNSL lesions usually appear in the vicinity of the ventricle, and are often multiple. Initial symptoms may include subclinical intracranial pressure and psychiatric conditions in addition to other conditions originating in the brain such as paralysis and aphasia [5]. PCNSL with hypothalamic-pituitary lesions has been rarely reported [6]. Here we report a case of PCNS $\mathrm{L}$ with the primary lesion in the hypothalamus, which

(C) The Author(s). 2021 Open Access This article is licensed under a Creative Commons Attribution 4.0 International License, which permits use, sharing, adaptation, distribution and reproduction in any medium or format, as long as you give appropriate credit to the original author(s) and the source, provide a link to the Creative Commons licence, and indicate if changes were made. The images or other third party material in this article are included in the article's Creative Commons licence, unless indicated otherwise in a credit line to the material. If material is not included in the article's Creative Commons licence and your intended use is not permitted by statutory regulation or exceeds the permitted use, you will need to obtain permission directly from the copyright holder. To view a copy of this licence, visit http://creativecommons.org/licenses/by/4.0/ The Creative Commons Public Domain Dedication waiver (http://creativecommons.org/publicdomain/zero/1.0/) applies to the data made available in this article, unless otherwise stated in a credit line to the data. 
was found by magnetic resonance imaging (MRI) after sudden onset of endocrinological abnormalities.

\section{Case presentation}

At 56 years of age, the patient was diagnosed with Connshing syndrome and received laparoscopic left adrenalectomy at another medical institution. He then started receiving hydrocortisone $(\mathrm{HC})$ replacement and was monitored for ACTH and cortisol levels. He was also diagnosed with an old myocardial infarction and started receiving aspirin (100 mg/day). At 57 year of age, he was transferred to our hospital due to his residential relocation. When he visited our hospital for the first time, his $\mathrm{ACTH}$ and cortisol $\geq 24 \mathrm{~h}$ after taking $2.5 \mathrm{mg}$ $\mathrm{HC}$ the previous morning were $48.6 \mathrm{pg} / \mathrm{ml}$ and $15.2 \mu \mathrm{g} /$ $\mathrm{dl}$, respectively, and his $\mathrm{HC}$ replacement was terminated.

Three months later, he began to suffer from blurred vision, headache and appetite loss, and was admitted to the emergency department of our institution. His height and body weight were $164.8 \mathrm{~cm}$ and $76.3 \mathrm{~kg}$, respectively. His vital signs were normal (blood pressure, 129/93 mmHg; pulse $82 \mathrm{bpm}$; body temperature $36.7^{\circ} \mathrm{C}$; $\mathrm{SpO}_{2}$ $96 \%$ ) and he showed no abnormalities in neurological or physical examinations that we routinely perform in clinical practice. However, his serum sodium concentration was $106 \mathrm{mEq} / \mathrm{L}$ and plasma osmolality was $217 \mathrm{mOsm} /$ $\mathrm{kgH}_{2} \mathrm{O}$ (Tables 1 and 2), and he was then hospitalized to our department. After hospitalization, his hyponatremia was corrected by intravenous and oral administration of sodium chloride, which, together with $\mathrm{HC}$ replacement from the 3rd day after hospitalization, improved his blurred vision, headache and appetite loss. In the morning of the 2nd day after hospitalization, levels of TSH, $\mathrm{ACTH}, \mathrm{GH}, \mathrm{LH}$ and FSH were low, and that of PRL was high (Table 3). On the 2nd day after hospitalization, his urinary cortisol was $\leq 15.5 \mu \mathrm{g} / \mathrm{dL}$, while plasma levels of
Table 2 Urinalysis upon admission to our emergency department

\begin{tabular}{ll}
\hline Specific gravity & 1.011 \\
$\mathrm{pH}$ & 6.0 \\
Protein & - \\
Glucose & - \\
Ketone body & + \\
Blood & + \\
Osmolarity & $439 \mathrm{mOsm} / \mathrm{kgH}_{2} \mathrm{O}$ \\
$\mathrm{Na}$ & $148 \mathrm{mEq} / \mathrm{L}$ \\
$\mathrm{K}$ & $36.6 \mathrm{mEq} / \mathrm{L}$ \\
$\mathrm{Cl}$ & $128 \mathrm{mEq} / \mathrm{L}$ \\
\hline
\end{tabular}

ACTH $(\mathrm{pg} / \mathrm{mL})$ and cortisol $(\mu \mathrm{g} / \mathrm{dL})$ were as follows: 8 am, 17.5 and $1.4 ; 2$ pm, 13.7 and 1.0; 8 pm 14.1 and 1.1; and $11 \mathrm{pm} 8.8$ and 0.8 , respectively. Little TSH and GH response was observed in TRH and GHRP-2 stimulation tests, respectively (Fig. 1a and d). Near normal LH and FSH responses were observed in GnRH stimulation test (Fig. 1b), but basal levels of LH and FSH were low (Table 3). Hyper ACTH response with low cortisol response was observed in CRH stimulation test (Fig. 1c). $\mathrm{ACTH}$ response was delayed with a low cortisol response and little $\mathrm{GH}$ response in insulin stimulation test (Fig. 1e). Peak cortisol level was $<18 \mu \mathrm{g} / \mathrm{dL}$ in $\mathrm{ACTH}$ rapid stimulation test, which was carried out $\geq 24 \mathrm{~h}$ after administration of $10 \mathrm{mg} \mathrm{HC}$ (Fig. 1f). These results indicated the presence of hypothalamic hypopituitarism and tertiary hypoadrenocorticism. The patient then experienced atypical visual field loss in his right eye. His MRI on day 14 after hospitalization revealed a rapidly growing tumor in the hypothalamus (Fig. 2a) that was absent 1 year before. Endoscopic biopsy of the tumor using a

Table 1 Biochemistry and complete blood count upon admission to our emergency department

\begin{tabular}{|c|c|c|c|c|c|}
\hline \multicolumn{4}{|l|}{ Biochemistry } & \multicolumn{2}{|c|}{ Complete blood count } \\
\hline Total protein & $7.6 \mathrm{~g} / \mathrm{dL}$ & Cre & $0.48 \mathrm{mg} / \mathrm{dL}$ & WBC & $5830 / \mu \mathrm{L}$ \\
\hline Albumin & $4.5 \mathrm{~g} / \mathrm{dL}$ & BUN & $5.3 \mathrm{mg} / \mathrm{dL}$ & Neutro & $51.9 \%$ \\
\hline CPK & $358 \mathrm{U} / \mathrm{L}$ & Total-cho & $171 \mathrm{mg} / \mathrm{dL}$ & Mono & $5.0 \%$ \\
\hline AST & $46 \mathrm{U} / \mathrm{L}$ & HDL-cho & $30 \mathrm{mg} / \mathrm{dL}$ & Lymph & $34.0 \%$ \\
\hline ALT & $77 \mathrm{U} / \mathrm{L}$ & TG & $205 \mathrm{mg} / \mathrm{dL}$ & Eosino & $8.6 \%$ \\
\hline $\mathrm{LDH}$ & $211 \mathrm{U} / \mathrm{L}$ & $\mathrm{Na}$ & $106 \mathrm{mmol} / \mathrm{L}$ & Baso & $0.5 \%$ \\
\hline ALP & $415 \mathrm{U} / \mathrm{L}$ & K & $4.2 \mathrm{mmol} / \mathrm{L}$ & $\mathrm{RBC}$ & $486 \times 10^{4} / \mu \mathrm{L}$ \\
\hline$\gamma$-GTP & $115 \mathrm{U} / \mathrm{L}$ & $\mathrm{Cl}$ & $77 \mathrm{mmol} / \mathrm{L}$ & $\mathrm{Hb}$ & $14.6 \mathrm{~g} / \mathrm{dL}$ \\
\hline $\mathrm{CHE}$ & $275 \mathrm{U} / \mathrm{L}$ & $\mathrm{Ca}$ & $9.2 \mathrm{mg} / \mathrm{dL}$ & Plt & $29.5 \times 104 / \mu \mathrm{L}$ \\
\hline AMY & $42 \mathrm{U} / \mathrm{L}$ & $\mathbb{I P}$ & $2.4 \mathrm{mg} / \mathrm{dL}$ & & \\
\hline UA & $2.3 \mathrm{mg} / \mathrm{dL}$ & BNP & $42.9 \mathrm{pg} / \mathrm{mL}$ & & \\
\hline CRP & $0.74 \mathrm{mg} / \mathrm{dL}$ & Glu & $127 \mathrm{mg} / \mathrm{dL}$ & & \\
\hline
\end{tabular}


Table 3 Basal levels of various hormones after normalization of hyponatremia

\begin{tabular}{llll}
\hline TSH & $0.06 \mu l U / m L$ & $P R L$ & $28.9 \mathrm{ng} / \mathrm{mL}$ \\
free T3 & $2.8 \mathrm{pg} / \mathrm{mL}$ & $\mathrm{LH}$ & $\leq 0.10 \mathrm{mlU} / \mathrm{mL}$ \\
free T4 & $0.71 \mathrm{ng} / \mathrm{dL}$ & FSH & $0.44 \mathrm{mlU} / \mathrm{mL}$ \\
ACTH & $4.2 \mathrm{pg} / \mathrm{mL}$ & PRA & $0.9 \mathrm{ng} / \mathrm{mL} / \mathrm{hr}$ \\
Cortisol & $7.9 \mu \mathrm{g} / \mathrm{dL}$ & PAC & $233.0 \mathrm{pg} / \mathrm{mL}$ \\
GH & $0.05 \mathrm{ng} / \mathrm{mL}$ & & \\
IGF-1 & $88 \mathrm{ng} / \mathrm{mL}(-1.8 \mathrm{SD})$ & & \\
\hline
\end{tabular}

ventriculoscope revealed a proliferation of atypical lymphocytes, which was positive for CD20 and CD79a (Fig. 3) as well as CD10 and Bcl-6 but negative for Bcl-2 (data not shown). The MIB-1 index was approximately $80 \%$ (Fig. 3). These results together suggested B-cell lymphoma. His serum level of soluble IL-2 receptor was $436.0 \mathrm{U} / \mathrm{mL}$ (normal range, 122$496 \mathrm{U} / \mathrm{mL}$ ), and examination of cerebrospinal fluid revealed no abnormalities.
He then started 6 courses of high-dose methotrexate $\left(3.5 \mathrm{~g} / \mathrm{m}^{2}\right)$ with stereotactic radiotherapy without whole brain radiotherapy $(20 \mathrm{~Gy})$ along with oral administration of $\mathrm{HC}$ (15 mg/day) and levothyroxine $(25 \mu \mathrm{g} /$ day $)$, which resulted in remission of the tumor (Fig. 2b). Some of the hormone responses (i.e., ACTH, TSH, PRL, LH and FSH), which were determined were normalized (Fig. 1).

Eight months after the initial hospitalization, he had a relapse of the tumor and received 3 courses of high dose

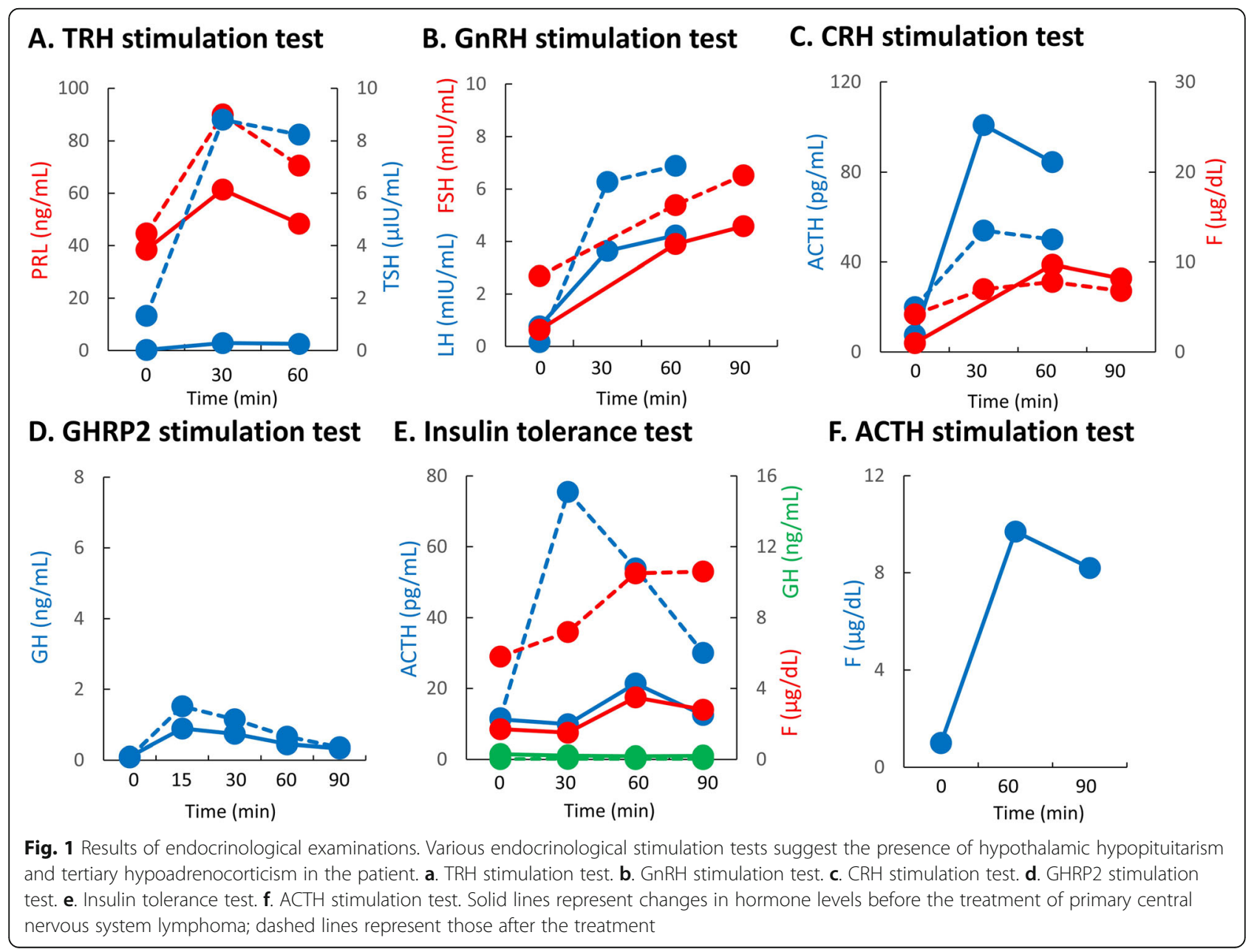




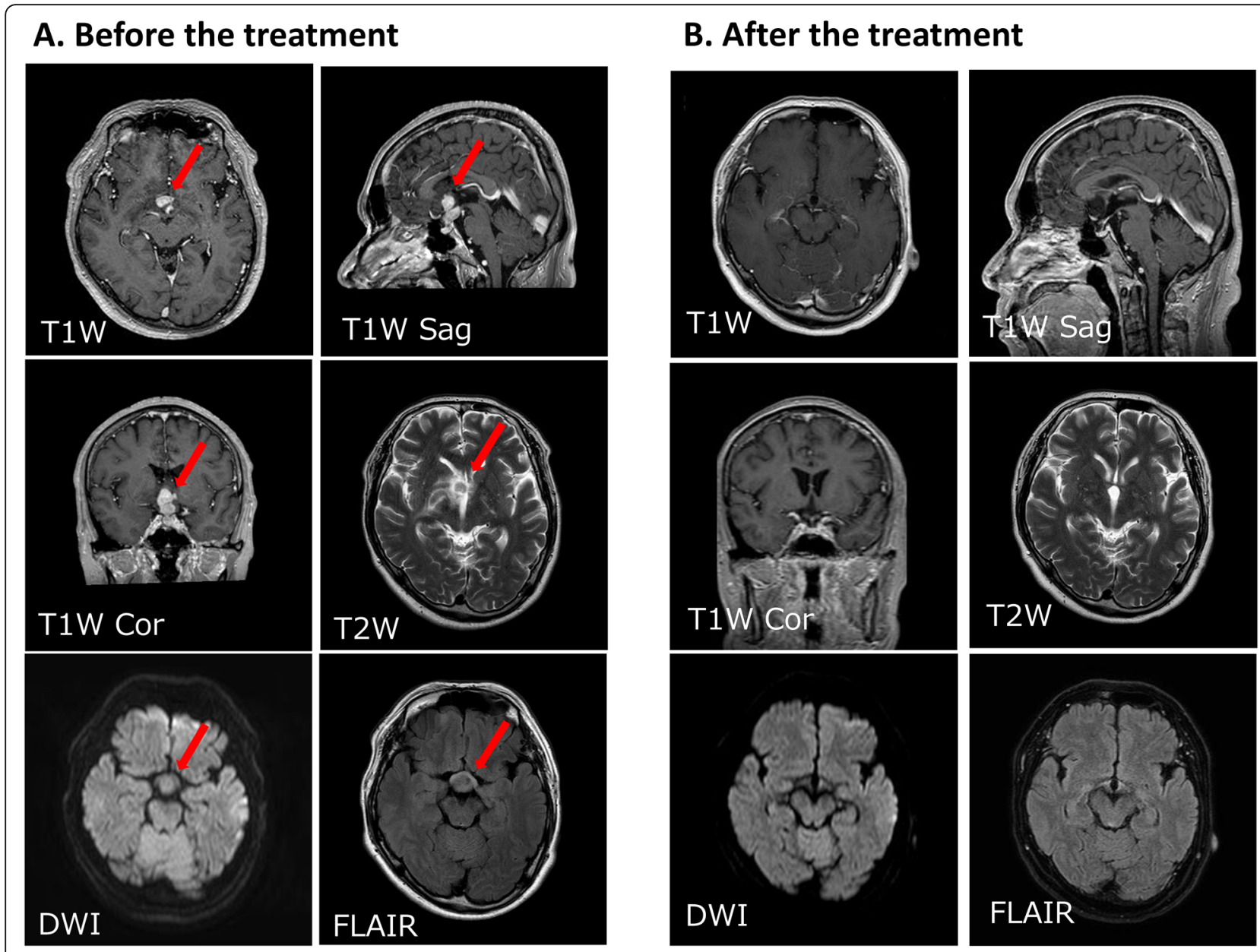

Fig. 2 Imaging analysis before and after the treatment of the central nervous system lymphoma. a, $\mathbf{b}$. Gadolinium-enhanced magnetic resonance imaging (MRI) before and after the initial treatment of the patient's central nervous system lymphoma. A $16 \times 12$ mm lobulated tumor mass in the hypothalamus that extends to the pituitary stalk and the right temporal lobe was detected as a low intensity mass in T2-weighted imaging, a faint high intensity mass in diffusion-weighted imaging, and fluid attenuated inversion recovery imaging (a). The mass was no longer detected after the treatment (b). T1, T1-weighted imaging; T2, T2-weighted imaging; DWI, diffusion-weighted imaging; FLAIR, fluid attenuated inversion recovery imaging; Sag, sagittal plane; Cor, coronal plane

methotrexate with whole brain radiotherapy (23.4 Gy), which resulted in another remission of the tumor. Twenty-two months after the initial hospitalization, he was hospitalized due to profound hyperthermia and disturbance of consciousness. Investigations including head MRI failed to find a cause of the hyperthermia, and hypothalamic dysfunction was suspected. His body temperature was high during summer and low during winter (Fig. 4a). He had increased appetite likely due to hypothalamic dysfunction, which resulted in body weight gain and fatty liver (Fig. 4b and c). He then started showing a gradual decline in cognitive function and activities of daily living. His head MRI at regular checkup revealed recurrence of the PCNSL at 38 months after the initial hospitalization; the patient died 39 months after the initial hospitalization.

\section{Discussion and conclusions}

Here we present a case of PCNSL with the primary lesion in the hypothalamus, which was found by MRI and assumed to be the cause of his hypopituitarism. While the patient's age and pathological findings are consistent with typical PCNSL cases, this case is exemplified by hyponatremia due to hypoadrenocorticism, which together prompted the diagnosis and reflect the localization of the tumor. PCNSL with hypothalamicpituitary lesions is extremely rare [7]. Symptoms of hypopituitarism may appear suddenly and quickly worsen as the tumor grows rapidly, as in the current case [8]. Indeed, we found a rapid decline in adrenal cortical function over a relatively short period of about 3 months. Importantly, secretions of some pituitary hormones (e.g., ACTH, TSH, PRL, LH and FSH) during 

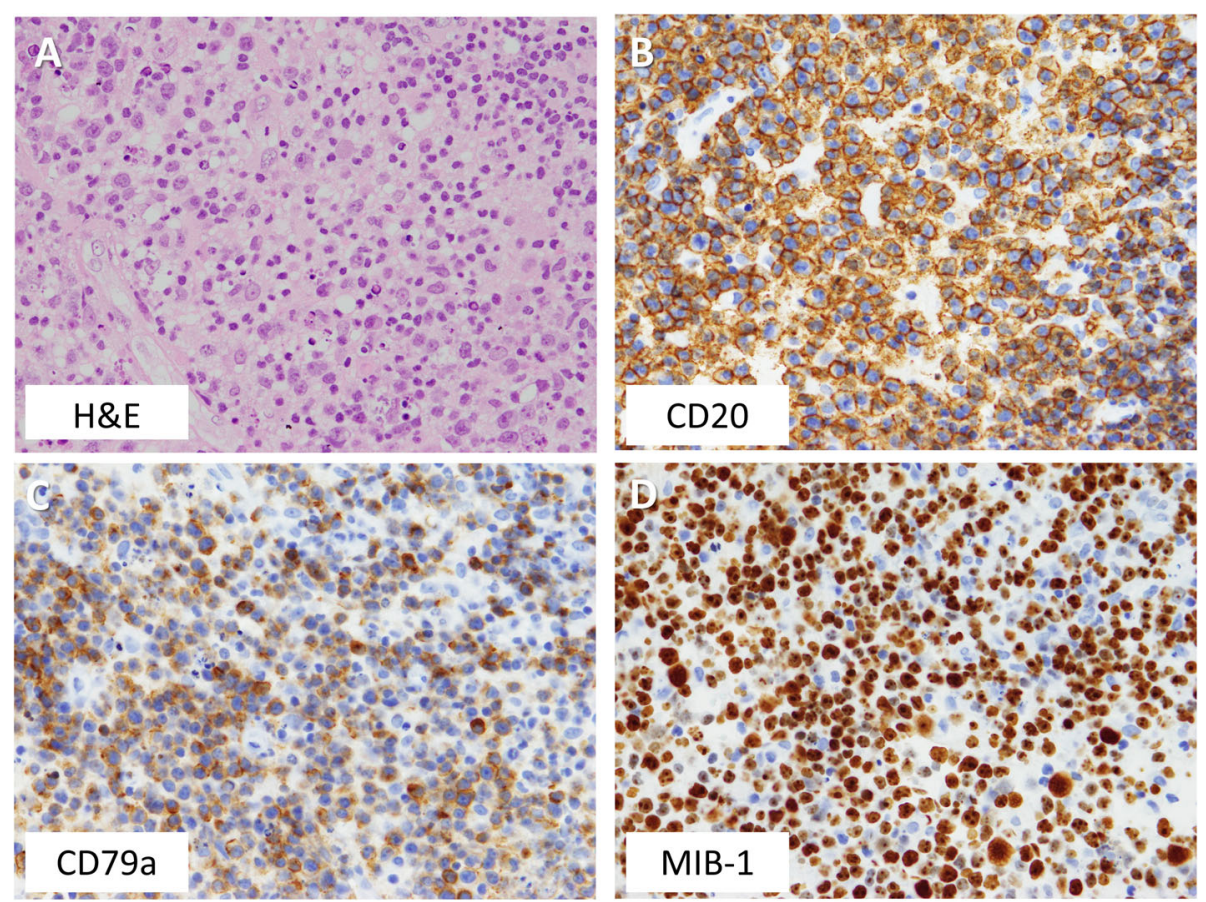

Fig. 3 Pathological analysis of the patient's tumor. The analysis found proliferation of atypical lymphocytes that were positive for CD20 and CD79a. MIB-1 index was approximately $80 \%$. Magnification $\times 400$

\section{A. Body temperature}

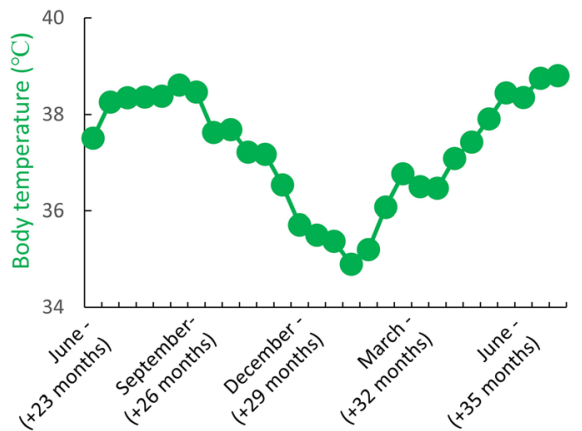

C. CT images of the liver
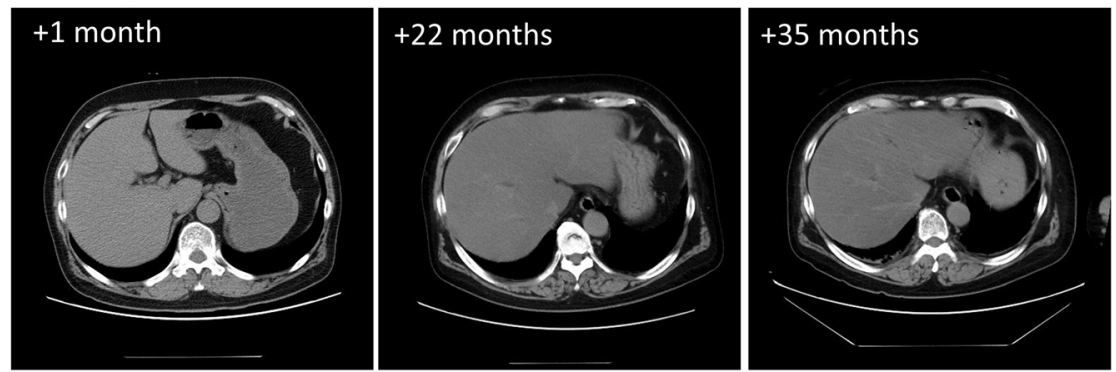

Fig. 4 Changes of body temperature, body weight and serum levels of alanine aminotransferase (ALT) and computer tomography (CT) images of the patient's liver. $\mathbf{a}$. His body temperature changed with the rise and fall of the ambient temperature, likely due to the impaired thermoregulatory center. $\mathbf{b}$. His body weight and ALT level gradually became elevated, likely due to dysregulated appetite. $\mathbf{c}$. The ratio of his liver-to-spleen (L/S) Hounsfield units on CT scan gradually declined (+ 1 month, 0.96; + 22 months, 0.42; and + 35 months, 0.37), likely due to worsening fatty liver [months after the initial hospitalization to our institution are shown as $+\mathrm{X}$ month(s)] 
various stimulation tests were partially improved by remission of the tumor, further suggesting infiltration and displacement of the hypothalamus and pituitary stalk as the cause of hypopituitarism in this case.

Risk factors for PCNSL include chronic use of immunosuppressants for organ transplants and autoimmune diseases in addition to immunodeficiency associated with HIV infection $[9,10]$. While the current case had been on $\mathrm{HC}$ replacement therapy before admission to our institution, because of the short duration and low dosage it is not likely that he was immunosuppressed. We did not investigate genetic alterations in the current case, but previous studies have shown the B-cell receptor pathway, which involves MYD88, CD79B and NF-kB activation, to be critical in the pathogenesis of PCNSL [11].

In conclusion, we treated a case of PCNSL with the primary lesion in the hypothalamus, which was found by MRI after sudden onset of endocrinological abnormalities. While PCNSL is rare, it is important to note that hypopituitarism can be caused by the disease and that endocrinological abnormalities can be partially restored by its remission.

\section{Abbreviations}

AIDS: Acquired immunodeficiency syndrome; MRI: Magnetic resonance imaging; PCNSL: Primary central nervous system lymphoma;

HC: Hydrocortisone

\section{Acknowledgements}

The authors also thank J. Kawada and M. Kato for their technical assistance, and M. Yato, Y. Ogiso and M. Nozu for their secretarial assistance.

\section{Authors' contributions}

$\mathrm{KT}, \mathrm{AT}, \mathrm{TS}$ and DY contributed to the analysis, collection, and interpretation of data and writing of the manuscript. YK, KN, YL, TK, MM, TH, ME, KI, YH, CS, $\mathrm{YK}, \mathrm{TM}, \mathrm{NO}$ and $\mathrm{Tl}$ contributed to the analysis, collection, and interpretation of data and critical revisions of the manuscript for important intellectual content. All authors approved the version to be published. DY and TS are the guarantors of this work.

\section{Funding}

This work was supported by grants from Japan Society for the Promotion of Sciences (JSPS) [KAKENHI Grant 17 K09825 (to D.Y.), 17 K00850 (to K.I) and $18 \mathrm{H} 02779$ (to Y.H.)].

\section{Availability of data and materials}

Clinical data from the corresponding author will be available upon request.

\section{Ethics approval and consent to participate}

Formal ethics approval was waived from the ethics committee of Gifu University Graduate School of Medicine because of a case report.

\section{Consent for publication}

Written informed consent was obtained from the family for publication of this report as the patient deceased 38 months after the initial diagnosis of PCNSL.

\section{Competing interests}

The authors declare that they have no competing interests to this study.

\section{Author details}

${ }^{1}$ Department of Diabetes and Endocrinology, Gifu University Graduate School of Medicine, 1-1 Yanagido, Gifu 501-1194, Japan. ²Division of
Pathology, Gifu University Hospital, Gifu, Japan. ${ }^{3}$ Department of Neurosurgery, Gifu University Graduate School of Medicine, Gifu, Japan.

Received: 11 July 2020 Accepted: 26 December 2020

Published online: 11 January 2021

References

1. Grommes C, DeAngelis LM. Primary CNS Iymphoma. J Clin Oncol. 2017; 35(21):2410-8.

2. Brain Tumor Registry of Japan (2005-2008). Neurol Med Chir (Tokyo). 2017; 57(Suppl 1):9-102

3. DeWitt JC, Mock A, Louis DN. The 2016 WHO classification of central nervous system tumors: what neurologists need to know. Curr Opin Neurol. 2017;30(6):643-9.

4. Brandsma D, Bromberg JEC. Primary CNS Iymphoma in HIV infection. Handb Clin Neurol. 2018;152:177-86.

5. Li L, Rong JH, Feng J. Neuroradiological features of lymphomatosis cerebri: a systematic review of the English literature with a new case report. Oncol Lett. 2018;16(2):1463-74.

6. Tanki HN, Malik KN, Makhdoomi R, Feroz S, Ramzan AU. Primary hypothalamic lymphoma in an adult male: a case report and literature review. Oman Med J. 2018:33(4):346-51.

7. Kuker W, Nagele T, Korfel A, Heckl S, Thiel E, et al. Primary central nervous system lymphomas (PCNSL): MRI features at presentation in 100 patients. $J$ Neuro-Oncol. 2005;72(2):169-77.

8. Giustina A, Gola M, Doga M, Rosei EA. Clinical review 136: primary lymphoma of the pituitary: an emerging clinical entity. J Clin Endocrinol Metab. 2001;86(10):4567-75.

9. Villano JL, Koshy M, Shaikh H, Dolecek TA, McCarthy BJ. Age, gender, and racial differences in incidence and survival in primary CNS lymphoma. $\mathrm{Br}$ Cancer. 2011:105(9):1414-8.

10. Su L, Ding M, Chen L, Li C, Lao M. Primary central nervous system lymphoma in a patient with systemic lupus erythematosus mimicking highgrade glioma: a case report and review of literature. Medicine (Baltimore). 2018;97(23):e11072.

11. Tsang M, Cleveland J, Rubenstein JL. On point in primary CNS Iymphoma. Hematol Oncol. 2000:38(5):640-7.

\section{Publisher's Note}

Springer Nature remains neutral with regard to jurisdictional claims in published maps and institutional affiliations.

Ready to submit your research? Choose BMC and benefit from:

- fast, convenient online submission

- thorough peer review by experienced researchers in your field

- rapid publication on acceptance

- support for research data, including large and complex data types

- gold Open Access which fosters wider collaboration and increased citations

- maximum visibility for your research: over $100 \mathrm{M}$ website views per year

At BMC, research is always in progress.

Learn more biomedcentral.com/submissions 